\title{
1 Hurdiid radiodontans from the middle Cambrian (Series 3) of Utah
}

3 Stephen Pates $^{1}$, Allison C. Daley ${ }^{1,2,3}$, and Bruce Lieberman ${ }^{4,5}$

$5 \quad{ }^{1}$ Department of Zoology, University of Oxford, Oxford, OX1 3PS, UK

$6 \quad<$ stephen.pates@zoo.ox.ac.uk>

$7 \quad{ }^{2}$ Oxford University Museum of Natural History, Oxford, OX1 3PW, UK

$8{ }^{3}$ Faculty of Geosciences and Environment, University of Lausanne, Sorge Géopolis, CH1015,

9 Lausanne, Switzerland <allison.daley@unil.ch>

$10{ }^{4}$ Division of Invertebrate Paleontology, Biodiversity Institute, University of Kansas, Lawrence,

11 KS 66045, USA <blieber@ku.edu>

$12{ }^{5}$ Department of Ecology and Evolutionary Biology, University of Kansas, Lawrence, KS 66045, 13 USA

15 Running Header: Hurdiids from the middle Cambrian of Utah

17 Abstract.-Radiodontan body elements, some belonging to Peytoia and Hurdia and some

18 unassigned, have been reported from the Langston Formation (Spence Shale Member), Wheeler

19 Formation, and Marjum Formation of the middle Cambrian (Series 3) of Utah. These

20 identifications are reassessed in light of recent work on the morphology of the radiodontan

21 Hurdia. New specimens of Hurdia are identified from the Spence Shale, representing mouthparts

22 (oral cones), cephalic carapace $\mathrm{H}$-elements, frontal appendages and a single isolated swimming

23 flap. The shape of the H-elements allows H. victoria to be identified from the Spence Shale for 
24 the first time. The flap is larger and more complete than any reported from the Burgess Shale,

25 and allows for a better understanding of the morphology of Hurdia swimming flaps. A 3D model

26 of a Hurdia frontal appendage indicates that there is only one morph of Hurdia frontal

27 appendage found in both species, and apparent morphological differences between disarticulated

28 appendages reflect a preservational continuum caused by varying oblique angles relative to the

29 seafloor. Peytoia should no longer be reported from the Spence Shale, but its presence is

30 confirmed in the Wheeler and Marjum formations. New mouthparts (oral cones) of Hurdia from

31 the Spence Shale and Peytoia from the Marjum Formation with surface textures of sub-

32 millimeter diameter raised nodes are described. These new features have not been observed in

33 material from the Burgess Shale, and suggest slight differences in preservation.

\section{Introduction}

37 Our understanding of the morphology and systematics of Hurdia Walcott, 1912 has greatly

38 expanded in recent years, and it is now recognized as a significant taxon within Radiodonta

39 present in several of the well-known Cambrian soft-bodied biotas including: the Burgess Shale in

40 Canada and the nearby Stanley Glacier, Marble Canyon, Tulip Beds and Mount Stephen sites

41 (Daley et al., 2009; 2013a); the Jince Formation in the Czech Republic (Chlupáč and Kordule,

42 2002, fig. 7); Wheeler Formation (Robison and Richards, 1981, pl. 4, fig. 1a,b) and the Spence

43 Shale (Daley et al., 2013a) in Utah, USA; the Shuinjingtuo Formation in China (Cui and Hou,

44 1990); and the Fezouata Biota in Morocco (Van Roy and Briggs, 2011, figs. 1d-i, S4a-c; 11,

45 S3c,d, S4f). Notably, the soft-bodied biotas from the middle Cambrian (Series 3) of Utah have

46 yielded a large number of specimens previously identified as radiodontans in general, and 
47 usually Anomalocaris Whiteaves, 1892 or Peytoia Walcott, 1911 (Daley and Bergström, 2012)

48 (e.g., Conway Morris and Robison, 1982; Briggs and Robison, 1984; Conway Morris and

49 Robison, 1988; Robison, 1991; Briggs et al., 2008), but the systematic position of most of this

50 material has not yet been re-evaluated in light of the new discoveries on Hurdia. By analysis of

51 appendages and mouthparts originally described in Conway Morris and Robison (1988) Daley et

52 al. (2013a) were able to conclude that Hurdia was in fact present in the middle Cambrian (Series

53 3) of Utah alongside Peytoia, and described four new specimens from the Spence Shale. Herein,

54 we reconsider the identifications of radiodontan specimens from Utah in detail and confirm that

55 Hurdia is well represented there. Further, we identify H. victoria in the Spence Shale for the

56 first time. A 3D model of an idealized Hurdia appendage potentially allows characters used in

57 previous phylogenetic analyses (e.g., Vinther et al., 2014; Cong et al., 2014; Van Roy et al.,

58 2015) to be visualized and evaluated in the hopes of possibly inferring which characters might be

59 influenced by taphonomic factors.

60 The middle Cambrian (Series 3) of Utah is well known for its soft-bodied deposits that

61 preserve a diverse array of taxa in several different depositional settings (Robison, 1991; Briggs

62 et al., 2008; Gaines et al., 2008, 2012; Brett et al., 2009; Halgedahl et al., 2009). The Gunther

63 family of Utah, along with Richard Robison (Robison, 1965; Gunther and Gunther, 1981),

64 played a pivotal role in helping this treasure trove of fossils come to light. Many significant

65 finds have been made from these deposits over the years (Resser, 1939; Brooks and Caster,

66 1956; Briggs and Robison, 1984; Babcock and Robison, 1988; Conway Morris and Robison,

67 1986, 1988; Robison and Wiley, 1995; Briggs et al., 2005), and new discoveries continue to be

68 made (Robison and Babcock, 2011; Stein et al., 2011; Conway Morris et al., 2015; LoDuca et

69 al., 2015; Robison et al., 2015). Taxa from these deposits have also provided insights into higher- 
70 level arthropod relationships (Hendricks and Lieberman, 2008) while forming a core source of

71 data used to study paleobiogeographic and macroevolutionary patterns during the Cambrian

72 radiation interval (Hendricks et al., 2008).

73 Non-hurdiid radiodontans reported from the Langston Formation (Spence Shale

74 Member), Wheeler Formation and Marjum Formation are limited to two body fossils of

75 Anomalocaris: one from the Spence Shale and one from the Wheeler Formation, both described

76 by Briggs et al. (2008, figs. 1, 3). Neither specimen has well preserved large frontal appendages,

77 and the two specimens seem to represent two different and new species. Isolated appendages of

78 Anomalocaris aff. canadensis Whiteaves, 1892, and Anomalocaris? sp. from the younger

79 (Guzhangian) Weeks Formation in Utah have been described by Lerosey-Aubril et al. (2014). No

80 new Anomalocaris appendages or bodies were identified during the course of this study. We

81 emphasize new findings relating to Hurdia and Peytoia.

82 As is the case for other radiodontans, Hurdia and Peytoia are found mostly as isolated

83 elements (carapace elements, mouthparts, appendages, and body flaps) and rarely as whole

84 bodies, which can at times make taxonomic identification challenging. In general, the

85 morphology of Hurdia can be divided into a head region with a pair of frontal appendages either

86 side of a circular oral cone. The oral cone made up of four large plates, equally spaced, with

87 seven small plates between each pair of large plates; these surround an opening with multiple

88 inner rows of teeth. A large frontal carapace of three sclerotized elements (two lateral P-elements

89 and one dorsal H-element) and stalked eyes complete the head region. The body is made up of

90 seven to nine segments, with reduced swimming flaps and prominent setal structures (Daley et

91 al., 2009; 2013a). A morphometric analysis showed that there are two species of Hurdia, $H$.

92 victoria and $H$. triangulata, which are differentiated by comparing the length and width of the 
93 carapace H-element (Daley et al., 2013a). Hurdia and Peytoia have recently been recovered

94 within Hurdiidae (e.g. Van Roy et al. 2015), but these genera differ in a number of ways. Peytoia

95 and Hurdia have a similar overall frontal appendage morphology in that both have elongated

96 ventral spines, but these differ in numerous details including the number and length-width ratio

97 of the podomeres, and the shape, arrangement and number of ventral spines (Daley et al., 2013a).

98 Hurdia has a complex frontal carapace composed of three sclerite elements, whereas Peytoia has

99 no evidence for such a large frontal carapace, with only traces of possible carapace material

100 immediately surrounding the head in ventrally preserved specimens (Daley et al. 2009). The oral

101 cone has the same arrangement of outer plates in Hurdia and Peytoia, but the multiple inner rows

102 of teeth present in Hurdia are absent in Peytoia. The body trunk in Hurdia consists of seven to

103 nine segments that are more cylindrical than the dorsaventrally flattened body of Peytoia, which

104 has 13 body segments. The swimming flaps of Hurdia are much smaller than the wide flaps of

105 Peytoia, but setal blades are more prominent in Hurdia as compared to Peytoia (Whittington and 106 Briggs, 1985, fig. 101).

107

\section{Materials and methods}

109

110 One body specimen (USNM 374593) is held at the Smithsonian Museum of Natural History,

111 Washington, D.C., USA. The remainder of the material studied is held at the Division of

112 Invertebrate Paleontology, Biodiversity Institute, University of Kansas, Lawrence, USA

113 (KUMIP). Detailed information for the fossil localities are available in Table 3 of Hendricks et

114 al. (2008). All specimen numbers, previous publications and new identifications are provided in

115 Table 1. 
$117 \mathrm{~mm}$ Macro Lens, controlled for remote shooting using the EOS Utility 2 program. Photographs

118 were taken under cross polarized light, non-polarized light, wet and dry, and under high and low

119 angle lighting. Measurements for calculating RI values, and length:width ratios were taken from

120 digital photographs using ImageJ 2.The 3D model was made using Blender 2.76b. A box model

121 was created from a sketch of Hurdia adapted from Daley and Budd (2010). This was modified

122 with a subdivision surface, and rendered to a video. A phylogenetic analysis in TNT v. 1.5

123 (Goloboff \& Catalano, 2016) was run using implicit enumeration under equal weighting on a

124 data matrix modified from Van Roy et al. (2015) consisting of 33 taxa and 61 characters.

125 Modifications to the phylogenetic analysis data matrix were made in Mesquite v. 3.2 (Maddison 126 and Maddison, 2017).

\section{Geologic setting}

129 The Spence Shale Member of the Langston Formation, middle Cambrian Series 3, Stage 5, is a 130 diverse soft-bodied biota (Gunther and Gunther, 1981; Robison, 1991; Liddell et al., 1997), and

131 knowledge of the paleontology, sedimentology, geochemistry, and taphonomy of this deposit has

132 increased substantially over the past few years (Briggs et al., 2008; Garson et al., 2012; Gaines et

133 al., 2012; Olcott Marshall et al., 2012; Gaines, 2014; Kloss et al., 2015). The Spence Shale is

134 primarily made up of shale, with some limestone, and it is developed in a series of parasequences

135 (Liddell et al., 1997; Garson et al., 2012). Detailed discussions of the sedimentology,

136 taphonomy, and geochemistry of the Spence Shale are provided by Liddell et al. (1997), Garson

137 et al. (2012), and Kloss et al. (2015), respectively. All of the specimens from the Spence Shale 
138 discussed herein come from the Wellsville Mountains of northern Utah (Hendricks et al., 2008;

139 Hendricks, 2013).

141 The Wheeler Formation, Drumian, Cambrian Series 3, from the House Range of Utah is slightly 142 younger than the Spence from the Wellsvile Mountains, and it too contains a diverse soft-bodied

143 biota (Robison, 1964; Gunther and Gunther, 1981; Briggs and Robison, 1984; Rogers, 1984;

144 Rees, 1986; Robison, 1991; Robison et al., 2015). There have been a substantial number of

145 relatively recent sedimentological, taphonomic, and geochemical studies of the soft-bodied biota

146 from this formation and region (e.g., Gaines and Droser, 2003, 2005; Briggs et al., 2008; Brett et

147 al., 2009; Halgedahl et al., 2009; Gaines, 2014). The unit consists of homogeneous mudstones

148 and interbedded mudstones with thin-grained, fine-bedded limestones. The soft-bodied material

149 occurs primarily within carbonaceous shales (Gaines and Droser, 2003, 2005).

151 The still slightly younger soft-bodied deposits from the Marjum Formation, Drumian, Cambrian

152 Series 3, generally resemble lithologically, stratigraphically and taphonomically those deposits

153 from the Wheeler Formation where it is exposed in the House Range (Elrick and Snider, 2002;

154 Brett et al., 2009; and Gaines and Droser, 2010), although they represent a shallower facies

155 (Briggs and Robison, 1984; Brett et al., 2009).

157 The relative global chronostratigraphic ages and polymerid trilobite biostratigraphy of

158 Radiodonta-preserving units in Utah and British Columbia can be seen in Figure 1.

160 Results 
162 Taxonomic identifications of new and previously described material are summarized in Table 1.

163 Hurdia victoria Walcott, 1912 is described for the first time from the Spence Shale. Hurdia also

164 occurs in the Wheeler Formation. Peytoia occurs in the Wheeler and Marjum formations, but

165 should no longer be reported as present in the Spence Shale.

167 Hurdia from the Spence Shale Member.- Some of the material interpreted as Hurdia from the

168 Spence Shale comprise appendages and mouthparts (Figs. 2, 3); these include both previously

169 described specimens (Briggs et al., 2008; Daley et al., 2013a, fig. 24) as well as new material.

170 New carapace material (Fig. 4.1-4.5), which allows identification to the species level, and a

171 large, isolated flap (Fig. 4.6, 4.7) are also discussed here for the first time. In addition,

172 appendages previously interpreted as Peytoia nathorsti (Conway Morris and Robison, 1988), are

173 here reinterpreted as belonging to a Sidneyia-like taxon.

174 KUMIP 314145a/b (Fig. 2.1) is a small, single incomplete Hurdia appendage with 7

175 visible podomeres with well-defined boundaries of around $1 \mathrm{~mm}$ in thickness. Podomeres at the

176 proximal end of the appendage where the ventral spines attach are not preserved. KUMIP

177314178 (Fig. 2.2) is a mostly complete small, single Hurdia appendage with ten podomeres

178 separated by clear podomere boundaries of around $1 \mathrm{~mm}$ thickness. KUMIP 314040a/b (Fig.

$1792.3,2.4)$ is a small Hurdia appendage with nine podomeres. Five large ventral spines, attached to

180 podomeres $2-6$, are tightly packed and appear curved forwards, beyond the distal end of the

181 appendage. Auxiliary spines are only visible on the distalmost ventral spine. KUMIP 314042

182 (Fig. 2.5) is a larger Hurdia appendage with ten podomeres with clear podomere boundaries of

183 around $1 \mathrm{~mm}$ thickness. The five large, straight ventral spines have slightly curved distal ends. 
185 appendages with mouthparts. The two appendages are preserved with one ('app. 1' in Fig. 3.3)

186 on a higher level of rock than the other ('app. 2' in Fig. 3.3). App. 1 is well preserved and made

187 up of ten podomeres. Large ventral spines are present on podomeres 2-6 and a small ventral

188 spine is visible on podomere 9 ('vs' in Fig. 3.3). A terminal spine is visible on podomere 10 ('ts'

189 in Fig. 3.3). App. 2 is not as clearly visible. The distalmost podomeres are visible. Three large

190 ventral spines are preserved together, with the distal one angled forwards, similar to the

191 overlying appendage. The mouthparts are made up of four large plates ('lp' in Fig. 3.3) arranged

192 at $90^{\circ}$ to each other around a rectangular opening. The total number of smaller plates is not clear,

193 as the outer edge of the oral cone is not well preserved, but where it can be counted there are

194 seven smaller plates between the large plates, which extrapolates to a total of 32 plates, four

195 large and 28 small, characteristic of Hurdia and Peytoia. By contrast, Anomalocaris mouthparts

196 have three large plates at $120^{\circ}$ (Daley and Bergström, 2012). Peytoia mouthparts can be

197 differentiated from Hurdia as Hurdia has numerous tooth rows in the central opening, whereas in

198 Peytoia the central opening lacks tooth rows (Daley and Bergström, 2012). In the central opening

199 of this specimen, additional tooth rows are visible ('tr' in Fig. 3.3), indicating this specimen is a

200 Hurdia. The appendages associated with the mouthparts are both consistent with this

201 interpretation, and are likely from the same animal. KUMIP 314175a/b (Fig. 2.6) is a small, oval

202 oral cone of Hurdia. It is unusual in that it has small raised nodes (radius $1 \mathrm{~mm}$ ) visible on one of

203 the large plates and several small plates. KUMIP 314265a/b (Fig. 2.7) is another small Hurdia

204 oral cone. The outer margins of the plates are not preserved, but multiple inner rows of teeth in

205 an approximately rectangular central opening are clearly visible. Again, there are some possible

206 small round nodes (radius $1 \mathrm{~mm}$ ) visible on some plates. 
208 distinguish $H$. victoria from $H$. triangulata: $H$. victoria has $\mathrm{H}$-elements with lengths greater than

2091.5 times the width (but less than 2.0 times) and $H$. triangulata has H-elements with lengths less

210 than 1.5 the width (Daley et al., 2013a). KUMIP 314039 (Fig. 4.2), KUMIP 314050 (Fig. 4.1,

211 4.4), and KUMIP 314056 (Fig. 4.3, 4.5), identified by height:width ratios, are the first $H$. victoria

212 specimens identified from the Spence Shale; H. triangulata has not yet been identified.

213 Reticulation polygons were observed on parts of the surface of some elements (Fig. 4.4). The

214 specimen illustrated in (Fig. 4.3, 4.5) has ten small brown patches (1-5 $\mathrm{mm}$ in radius) and a

215 trilobite with inferred manganese dendrites radiating from it, obscuring parts of the fossil.

216 Similar dendrites with elevated manganese content have been reported from the Pioche Shale

217 (Moore and Lieberman, 2009). Evidence for the two-layered H-element can be seen towards the 218 strengthened tip (Fig. 4.5).

219 KUMIP 314057a/b (Fig. 4.6, 4.7) is a part and counterpart of an isolated radiodontan swim 220 flap covered with regularly spaced, prominent transverse lines, also referred to as "strengthening 221 rays" (Whittington and Briggs, 1985) or "veins" (Chen et al., 1994; Hou et al., 1995), about 1 $222 \mathrm{~mm}$ wide and $2 \mathrm{~mm}$ apart. The flap is relatively large compared to Hurdia flaps reported from the 223 Burgess Shale (Daley et al., 2013a), measuring approximately $65 \mathrm{~mm}$ in width and $45 \mathrm{~mm}$ in

224 height. This specimen is tentatively identified as Hurdia because of the presence of transverse 225 lines across the entire surface of the flap, which is not seen in Peytoia (where the transverse lines 226 are confined to the anterior half of the flap) or Anomalocaris (which lacks transverse lines 227 entirely). 
Sidneyia? from the Spence Shale Member.-Conway Morris and Robison (1988, fig. 26.1a,

$23026.1 b, 26.2$ ) identified four specimens (KUMIP 204777-204780) as broken spines of Peytoia

231 nathorsti appendages. These are reinterpreted as distal podomeres of endopods (walking

232 appendages) of a Sidneyia-like taxon, based on the rounded curvature of the overall structure, the

233 oblique angle of the spines, the characteristic arrangement of repetitive bundles of decreasing

234 spine size, and the presence of podomere boundaries faintly visible on some specimens (compare

235 KUMIP 204777-204780: Conway Morris and Robison, 1988, fig. 26.1a, 26.1b, 26.2 to Bruton,

236 1981, figs. 48, 53, 55, 58, 60, 88, 92 and Stein, 2013, fig. 7B-D). This therefore indicates

237 Peytoia should no longer be reported as present in the Spence Shale. Sidneyia was previously

238 reported from the Spence Shale (Briggs et al., 2008).

240 Hurdiids from the Wheeler Formation.-Hurdia is known from the Wheeler Formation by a

241 single P-element. Peytoia is known from one appendage and several mouthparts. KUMIP

242 153901a/b (Fig. 5.6, 5.7) was first described by Robison and Richards (1981, pl., 4, fig. 1a, b) as

243 Proboscicaris agnosta, which at the time was thought to be a phyllocarid. Proboscicaris is now

244 identified as the P-element of the Hurdia carapace (Daley et al., 2009). KUMIP 314086a/b (Fig.

245 5.1, 5.2) was first described by Briggs et al. (2008, fig. 2.2) as a radiodontan appendage. Owing

246 to the relatively limited preservation, they did not classify it to genus. It is an appendage with 10

247 podomeres, with elongated ventral spines on podomeres 2-6. Six auxiliary spines are present

248 perpendicular to the ventral spine of podomere 5. There are three small triangular terminal spines

249 on podomere 10 . The presence of three terminal spines, the orientation of ventral spines, and the

250 curved distal end indicate it is a Peytoia appendage. Conway Morris and Robison (1982, text-

251 fig. 1, pl. 1 figs. 1-5) described two specimens, KUMIP 153093a/b (Fig. 5.10, 5.11) and KUMIP 
252153094 (Fig. 5.5), of radiodontan oral cones as Peytoia cf. P. nathorsti, and we support this 253 interpretation based on the overall arrangements of plates, and the lack of tooth rows inside the

254 main opening. The genuine absence of additional rows of teeth can be confirmed by examining 255 the central opening, which well preserved. KUMIP 314078 (Fig. 5.8, 5.9), first described by 256 Briggs et al. (2008, fig. 2.2), is an oral cone with four large plates, and seven smaller plates 257 between each larger plate. Part of the mouth apparatus is not preserved, but it can be inferred that 258 it had 32 plates (four large, 28 small) radially arranged. The central opening of the incomplete 259 mouth apparatus does not have additional tooth rows, so it can be identified as Peytoia. 260 Conway Morris and Robison (1988, fig. 26.3) identified KUMIP 204781a/b (Fig. 5.3, 261 5.4) from the Wheeler Formation as a P. nathorsti appendage. A previous taxonomic analysis 262 (Daley et al., 2013a) suggested that this was potentially a Hurdia appendage. As the distal end of 263 the appendage is not preserved and the morphology of the ventral spines is not conclusive, it is 264 identified here as a hurdiid, but no identification to the genus level is made.

266 Peytoia from the Marjum Formation.-Hurdia is not known from the Marjum Formation. Briggs 267 and Robison (1984) identified USNM 374593 (Figs. 6, 7) from the Marjum Formation as a 268 partial body (lacking frontal appendages) of Peytoia nathorsti, based on the presence of 269 transverse lines on the flaps. These had only been observed in P. nathorsti and not 270 Anomalocaris canadensis, which at the time was the only other radiodontan body type known.

271 We support placement in Peytoia because of the presence of large posterior-tapering swim flaps

272 (in contrast to the small flaps of Hurdia) with transverse lines (which are absent in

273 Anomalocaris), and the absence of a tail fan (present in Hurdia and Anomalocaris). The

274 specimen consists of the 11 most posterior segments and tail of the animal, with flaps and central 
275 body structures preserved together. There is slight overlap of the anterior and posterior edges of 276 the flaps, and the presence of some high-relief mineralized structures (Fig. 7, described below).

277 A dark brown-grey linear structure ('ba' in Fig. 6.5) runs down the median axis of the animal, 6-

$2787 \mathrm{~mm}$ wide near the anterior, tapering to a point and disappearing as it reaches the pair of body

279 flaps. This region has a very thin ( $1 \mathrm{~mm}$ wide) feature at its midline running along the length of

280 the body, particularly visible in the counterpart (' $\mathrm{g}$ ' in Fig. 6.5). This is interpreted to be the gut

281 running through the body cavity. It is flanked on both sides by a series of bilaterally symmetrical

282 dark grey features ('s1-s11' in Fig. 6.5). They are larger anteriorly ( $3 \times 25 \mathrm{~mm})$ than posteriorly

$283(1.5 \times 10 \mathrm{~mm})$, and are interpreted as setal blade blocks on account of their preservation, position

284 and co-occurrence with body flaps. Lateral to the setal blade structures, and partly overlapping

285 them, there is a series of dark reflective structures with high relief, present in the region where

286 the base of the flaps meets the axial region ('m1-m6' in Fig. 6.5). These structures are

287 interpreted as musclulature on account of similarities between them and musculature in

288 Anomalocaris canadensis (Daley and Edgecombe, 2014, figs. 15, 17). Both have a fibrous

289 texture (Fig. 7.3-7.5) are similar in size and shape (Fig. 7) and are at the base of body flaps (Fig.

290 7.1, 7.2). In A. canadensis these structures are preserved as an orange material, or as a high relief

291 dark grey to black reflective material. In Peytoia (USNM 374593) they are similarly preserved as

292 high relief dark reflective material, although the fibrous details are less well preserved than in $A$.

293 canadensis (compare Fig. 7.3, 7.5 to Fig. 7.4). They are not interpreted as gut diverticulae, which

294 are often preserved as high relief dark reflective material, as they do not intersect the gut, and are

295 instead associated with the intersection of the body flaps with the cuticularized body, far from

296 the body axis. However it must be noted that euarthropod gut diverticulae are preserved in a

297 variety of ways (Lerosey-Aubril et al., 2012), and the preservation of this musculature is 
different from musculature reported from some other Burgess-Shale type localities:

299 Pambdelurion from Sirius Passet (Budd, 1998); and Myoscolex from the Emu Bay Shale (Briggs 300 and Nedin, 1997).

The second most anterior flap on the right side of the counterpart preserves a set of highrelief linear structures near its base, located between the musculature of this flap and the flap in 303 front of it (Fig. 6.4, 'st' in Fig. 6.5). The six parallel, evenly spaced structures are mineralized, 304 and although they are closely packed, they do not touch one another. The longest one, closest to 305 the body axis, is just under $1 \mathrm{~mm}$ in length, and the structures become shorter away from the 306 body axis, with the shortest one just under $0.5 \mathrm{~mm}$ in length. $2 \mathrm{~mm}$ below the linear structures 307 there are a number of circular mineralized structures, around 0.25 to $0.5 \mathrm{~mm}$ in diameter. Small 308 spheres $0.5 \mathrm{~mm}$ in diameter are present on other phosphatized blocks. Similar structures, which 309 were identified as clusters of pyrite framboids, have been reported from the middle Cambrian 310 (Series 3) Pioche Shale by Moore and Lieberman (2009). Transverse lines only cover the 311 anterior portion of the flap (Fig. 6.3), and no internal structure of the flaps is preserved, similar to 312 P. nathorsti from the Burgess Shale (Whittington and Briggs, 1985). Ten large ventral flaps 313 ('vf1-vf10' in Fig. 6.5) are preserved on the side that most clearly shows a dorsal flap ('df1' in 314 Fig. 6.5), and six large ventral flaps are preserved on the other side ('vf1-vf6' in Fig. 6.5), with 315 one dorsal flap preserved there also ('df1' in Fig. 6.5). The front pair of flaps is the largest, and 316 they reduce in size sequentially. The flaps associated with body segments $7-11$ are overlapping 317 due to the orientation of preservation. There are no flaps associated with the tail (' $t$ ' in Fig. 6.5). 318 On the part, two dorsal flaps are also preserved at the front of the animal, in addition to the larger 319 ventral flaps ('df1' in Fig. 6.5). 
321 the visible plate morphology and lack of internal tooth rows. One large plate with large triangular

322 inner spines is preserved, with five smaller plates on one side and seven on the other side of the

323 large plate. These smaller plates are a regular size and overlap each other, with the plate closer to

324 the large plate overlapping the one next closest. The partially preserved central opening shows

325 no evidence of additional rows of teeth. The large plate has 10 small triangular spines pointing

326 inwards, the widest of which, at a central point of the plate, is around $2 \mathrm{~mm}$. The others are

327 smaller, at around $1 \mathrm{~mm}$ wide. Some of the smaller plates have a single projection also pointing

328 inwards, around $1 \mathrm{~mm}$ wide. Unusually for Peytoia this mouthpart has small (diameter

329 approximately $0.3 \mathrm{~mm}$ ) nodes on the surface of the large plate, and some adjacent plates (visible

330 on both part and counterpart, Fig. 6.6, 6.7).

\section{Discussion}

\section{Morphological interpretations on Hurdia appendages can be influenced by specimen}

335 orientation.-Hurdia appendages are preserved in a variety of orientations (see Daley et al.,

336 2013a). Ventral spines of Hurdia are often preserved curved, both anteriorly (e.g. Fig. 2.3, 2.4)

337 and posteriorly (e.g. Fig. 2.1, 2.2) and straight (e.g. Figs. 2.5, 3), sometimes in the same

338 specimen (e.g. Daley et al., 2009, fig. 2C). The appendages have some element of plasticity, and

339 during preservation they can become deformed. In some specimens the curvature of ventral

340 spines appears to change along the length of the appendage, due to the appendage being

341 preserved at an angle (e.g. Daley et al., 2013a, figs. 12C, E, 24A, where the distalmost ventral

342 spines appear more curved as the appendage is rotated one way, and Daley et al., 2013a, fig.

$34312 \mathrm{G}$, where the proximalmost ventral spines appear more curved as the appendage is rotated the 
344 other way). Appendages not preserved at such angles tend to have the distalmost podomeres

345 more clearly preserved, not overlapping more proximal podomeres (compare the position of the

346 distalmost podomeres in Fig. 3 and Daley et al., 2013a, fig. 12A, to those described as rotated

347 above).

348 The impact that these preservational factors might have on morphological reconstructions

349 and inferred evolutionary affinities can be observed by considering phylogenetic analyses of

350 Radiodonta. Recent phylogenies (Cong et al., 2014; Van Roy et al., 2015) based on the data

351 matrix and analysis of Vinther et al. (2014) consider four distinct representatives of Hurdia: $H$.

352 victoria, $H$. cf. victoria Utah, $H$. sp. B Spence Shale, and $H$. sp. B Burgess Shale (the latter two

353 were coded identically except for missing character states). Other than missing character states,

354 H. victoria and H. cf. victoria Utah only differ in the condition of character 29: Vinther et al.

355 (2014) coded $H$. victoria as having distally projecting dorsal spines on the terminal segments;

356 these were coded as absent in Hurdia cf. victoria Utah. Vinther et al. (2014) coded Hurdia

357 victoria (including Hurdia cf. victoria Utah) and $H$. sp. B as differing in three characters. In

358 character 34 , the ventral spines were coded as broader distally than proximally in Hurdia

359 victoria, and subequal or narrower distally in Hurdia sp. B. In character 39, the distal tips of the

360 ventral spines are hooked forward in Hurdia victoria, but strongly hooked forward and forming a

$36190^{\circ}$ angle with the spine base in Hurdia sp. B. The phylogenetic significance of characters 29 ,

36234 , and 39 may be called into question by the aforementioned preservational variation. Similarly,

363 character 46 (curvature of ventral spines) may reflect preservational rather than taxonomic

364 variation. Hurdia sp. B was coded as having proximal ventral spines that curve posteriorly,

365 whereas $H$. victoria was coded as having ventral spines all straight or anteriorly curved.

366 However, H. victoria specimens with straight proximal ventral spines and anteriorly curving 
367 distal ends are common (e.g. Daley et al., 2013, fig. 12 A, C, E, G) and this reflects taphonomic 368 variation.

369 To visualize how the angle of preservation influences morphological interpretations of

370 Hurdia appendages, a 3D model was created in Blender based on the morphology of the Hurdia

371 appendage in Daley and Budd (2010, text-fig. 1D). This 3D model (Fig. 8) suggests that the

372 apparent broadness of ventral spines on distal podomeres will be influenced by how a specimen

373 is oriented when it is preserved, and so the broadness of ventral spines (Vinther et al., 2014,

374 Character 34) is likely not a good character for distinguishing Hurdia species. A small difference

375 in orientation affecting apparent thickness of ventral spines can be seen by comparing KUMIP

376314086 (Fig. 5.1, 5.2, with ventral spines of equal thickness) and KUMIP 314042 (Fig. 2.5,

377 where the distalmost ventral spine appears thicker because of its orientation). This is visualized

378 by the 3D model, where Fig. 8.1 (no rotation) shows ventral spines of equal thickness, and Fig.

3798.2 (small rotation) shows an apparently thicker distalmost ventral spine. A more extreme

380 example of the variation in the orientation of appendage preservation can be seen in the two

381 appendages of KUMIP 312405 (Fig. 3). These appendages are presumably from the same animal

382 but preserved at very different orientations.

383 In summary Vinther et al.'s (2014) characters 29, 34, 39, and 46, which comprise the

384 evidence to distinguish four different representatives of Hurdia, may be influenced by

385 preservational factors. A phylogenetic analysis of the data matrix from Van Roy et al. (2015),

386 which is based on the original data matrix of Vinther et al. (2014), was run in TNT v. 1.5 using

387 implicit enumeration under equal weighting. The data matrix was modified in the following

388 ways: In Character 29, $H$. cf. victoria Spence is coded as dorsal spines present, and both $H$. sp. B

389 taxa are coded as unknown; Character 34 was deleted as is has been shown to reflect 
390 preservation and not true morphological difference; Character 39 (now Character 38) was

391 changed to being unordered, and both $H$. sp. B taxa and Stanleycaris were coded as having

392 hooked forward ventral spines; and in Character 46 (now Character 45), both Hurdia sp. B taxa

393 are coded as having straight or curved anterior ventral spines. An analysis under equal weighting

394 recovers 70 most parsimonious trees of 106 steps, and in strict consensus $(\mathrm{CI}=0.66, \mathrm{RI}=0.85)$ all

395 four Hurdia taxa and Stanleycaris are recovered in an unresolved polytomy. This is in contrast to

396 the resolved relationships depicted in Vinther et al. (2014) and Van Roy et al. (2015), where the

397 two $H$. sp. B specimens form a clade that is sister to Stanleycaris, rather than to H. victoria.

398 Based on current evidence Hurdia cannot be identified to the species level by its frontal

399 appendages alone, and appendages from the Spence Shale and the Burgess Shale cannot be

400 distinguished as KUMIP 314040 and 314178, described herein, show that Hurdia appendages

401 from Utah do possess dorsal spines (Fig. 2.2-2.4). Hurdia can still only be separated into two

402 distinct species by the shape of its H-element (Daley et al., 2013a).

403

404 Presence of nodes on mouthparts. - Nodes are present on the plates of Hurdia mouthparts from

405 the Spence Shale (KUMIP 314175a/b and 314265a/b, Fig. 2.6, 2.7) and partial Peytoia

406 mouthparts from the Marjum Formation (KUMIP 314095, Fig. 6.6, 6.7). Nodes are not often

407 seen in Burgess Shale specimens. The nodes are similar to what is seen in Anomalocaris (e.g.,

408 Daley and Bergström, 2012, fig. 2a-d; Daley and Edgecombe, 2014, fig. 7.5). However, the

409 plates of these mouthparts lack the subdivisions and furrowing on the outer margins that is often

410 seen in Anomalocaris (e.g. Daley and Bergström, 2012, fig. $2 \mathrm{~g}-\mathrm{j}$ ). The presence of nodes in the

411 Utah specimens could be due to interspecific variation, however, a more likely cause is

412 preservational differences, which allow more 3D structure to be preserved in Utah than in 
413 Burgess Shale specimens. Similar preservational differences are seen in the oral cones of $A$.

414 canadensis, where nodes are preserved in varying degrees of relief in oral cones from the

415 Burgess Shale and the Emu Bay Shale (Daley et al., 2013b, Daley and Bergström, 2012).

417 Geographical and temporal distribution of hurdiids.-Hurdia and Peytoia are distributed over a

418 large temporal and geographic range (Table 2). Both are reported from China, the USA, and

419 Canada. Hurdia is known additionally from the Czech Republic (Chlupáč and Kordule, 2002),

420 and Peytoia from Poland (Daley and Legg, 2015). This study shows that Peytoia is not known

421 from the Spence Shale. This does not have any implications for the first or last appearance of

422 Peytoia, as its oldest occurrence is from Holy Cross Mountains (Daley and Legg, 2015) and it is

423 reported from the younger Marjum Formation (Briggs and Robison, 1984, this study), however it

424 does change the earliest known occurrence of P. nathorsti to the Burgess Shale. Hurdia is not yet

425 known from the Marjum Formation, however it is reported from the younger Fezouata

426 Lagerstätten (Van Roy and Briggs, 2011). As Hurdia and Peytoia do not co-occur in the Spence

427 Shale or Marjum Formations, a potential hypothesis is that the similarities of their frontal

428 appendages, and hence similar predation methods prevented the two genera from co-existing.

429 Indeed, a recent morphospace analysis of the first appendages of 36 euarthropod taxa (Aria and

430 Caron, 2015) supports functional similarities in the feeding appendages of Peytoia and Hurdia,

431 which plotted close together. However, Hurdia and Peytoia do co-occur in the Wheeler

432 Formation, Tulip Beds and Burgess Shale (Table 2), suggesting that they were capable of co-

433 existing in the right environment, and the collection of more hurdiids from the Spence Shale and

434 Marjum Formation may in fact show that Peytoia and Hurdia are present where currently they

435 are not known. 


\section{Acknowledgments}

439 M. Florence provided access to the specimen at the USNM. We thank the editor Jisuo Jin,

440 Associate Editor Z. Zhang, an anonymous reviewer and J. Ortega-Hernandez for their valuable

441 comments, and P. Selden (University of Kansas) for use of photographic equipment. The

442 program TNT was made available with the sponsorship of the Willi Hennig Society. Funding

443 was provided by a Palaeontological Association Sylvester-Bradley Award (PA-SB201503) to

444 SP, the OUMNH to ACD and NSF-EAR-0518976 to BSL.

\section{References}

447 Aria, C., and Caron, J.B., 2015, Cephalic and limb anatomy of a new isoxyid from the burgess 448 shale and the role of "stem bivalved arthropods" in the disparity of the frontalmost 449 appendage: PloS one, v. 10, p. e0124979.

450 Babcock, L.E., and Robison, R.A., 1988, Taxonomy and paleobiology of some Middle Cambrian $451 \quad$ Scenella (Cnidaria) and hyolithids (Mollusca) from western North America: University of 452 Kansas Paleontological Contributions, v. 121, p. 1-22.

453 Brett, C.E., Allison, P.A., DeSantis, M.K., Liddell, W.D., and Kramer, A., 2009, Sequence 454 stratigraphy, cyclic facies, and lagerstätten in the Middle Cambrian Wheeler and Marjum 455 formations, Great Basin, Utah: Palaeogeography, Palaeoclimatology, Palaeoecology, v. 456277, p. $9-33$. 
457 Briggs, D.E., and Nedin, C., 1997, The taphonomy and affinities of the problematic fossil Myoscolex from the Lower Cambrian Emu Bay Shale of South Australia: Journal of Paleontology, v. 71, p.22-32.

Briggs, D.E., and Robison, R.A., 1984, Exceptionally preserved nontrilobite arthropods and Anomalocaris from the Middle Cambrian of Utah: University of Kansas Paleontological Contributions, v. 111, p. 1-23.

Briggs, D.E., Lieberman, B.S., Halgedahl, S.L. and Jarrard, R.D., 2005, A new metazoan from the Middle Cambrian of Utah and the nature of the Vetulicolia: Palaeontology, v. 48, p.

Briggs, D.E., Lieberman, B.S., Hendricks, J.R., Halgedahl, S.L. and Jarrard, R.D., 2008, Middle Cambrian arthropods from Utah: Journal of Paleontology, v. 82, p. 238-254.

Brooks, H.K., and Caster, K.E., 1956, Pseudoarctolepis sharpi, n. gen., n. sp.(Phyllocarida), from the Wheeler Shale (Middle Cambrian) of Utah: Journal of Paleontology, v. 30, p. 9 14.

Bruton, D.L., 1981, The arthropod Sidneyia inexpectans, Middle Cambrian, Burgess Shale,

474 Budd, G.E., 1998, Stem group arthropods from the Lower Cambrian Sirius Passet fauna of north Greenland, in Fortey, R. A., and Thomas, R. H., ed., Arthropod relationships, p. 125-138. Springer Netherlands.

477 Caron, J.B., Gaines, R.R., Mángano, M.G., Streng, M., and Daley, A.C., 2010, A new Burgess Shale-type assemblage from the "thin" Stephen Formation of the southern Canadian Rockies: Geology, v. 38, p. 811-814. 
Chen, J.Y., Ramsköld, L., and Zhou, G.Q., 1994, Evidence for monophyly and arthropod affinity of Cambrian giant predators: Science, v. 264, p. 1304-1308.

Chlupáč, I., and Kordule, V., 2002, Arthropods of Burgess Shale type from the Middle Cambrian of Bohemia (Czech Republic): Bulletin of the Czech Geological Survey, v. 77, p. 167-182.

Cong, P., Ma, X., Hou, X., Edgecombe, G.D., Strausfeld, N.J., 2014, Brain structure resolves the segmental affinity of anomalocaridid appendages: Nature, v. 513, p. 538-542.

Conway Morris, S., and Robison, R.A., 1982, The enigmatic medusoid Peytoia and a comparison of some Cambrian biotas: Journal of Paleontology, v. 56, p. 116-122.

Conway Morris, S., and Robison, R.A., 1986., Middle Cambrian priapulids and other soft-bodied fossils from Utah and Spain: University of Kansas Paleontological Contributions, v. 117, p. 1-22.

Conway Morris, S., and Robison, R.A., 1988, More soft-bodied animals and algae from the Middle Cambrian of Utah and British Columbia: University of Kansas Paleontological Contributions, v. 122 , p. $1-48$

497 Cui, Z., and Huo, S., 1990, New discoveries of Lower Cambrian crustacean fossils from Western Hubei: Acta Palaeontologica Sinica, v. 29, p. 321-330.

499 Daley, A.C., and Bergström, J., 2012, The oral cone of Anomalocaris is not a classic “'Peytoia”': Naturwissenschaften, v. 99, p. 501-504. Canada: Palaeontology, v. 53, p. 721-738. 
Daley, A.C., and Edgecombe, G.D., 2014, Morphology of Anomalocaris canadensis from the

$504 \quad$ Burgess Shale: Journal of Paleontology, v. 88, p. 68-91.

505 Daley, A.C., and Legg, D.A., 2015, A morphological and taxonomic appraisal of the oldest

$506 \quad$ anomalocaridid from the Lower Cambrian of Poland: Geological Magazine, v. 152, p. 949-

$507 \quad 955$.

508 Daley, A.C., Budd, G.E., Caron, J.B., Edgecombe, G.D. and Collins, D., 2009, The Burgess

509 Shale anomalocaridid Hurdia and its significance for early euarthropod

510 evolution: Science, v. 323, p. 1597-1600.

511 Daley, A.C., Budd, G.E. and Caron, J.B., 2013a, Morphology and systematics of the

512 anomalocaridid arthropod Hurdia from the Middle Cambrian of British Columbia and

$513 \quad$ Utah: Journal of Systematic Palaeontology, v. 11, p. 743-787.

514 Daley, A.C., Paterson, J.R., Edgecombe, G.D., García-Bellido, D.C. and Jago, J.B., 2013b, New

515 anatomical information on Anomalocaris from the Cambrian Emu Bay Shale of South

$516 \quad$ Australia and a reassessment of its inferred predatory habits: Palaeontology, v. 56, p. 971-

517990.

518 Elrick, M., and Snider, A.C., 2002, Deep-water stratigraphic cyclicity and carbonate mud mound 519 development in the Middle Cambrian Marjum Formation, House Range, Utah,

$520 \quad$ USA: Sedimentology, v. 49, p. 1021-1047.

521 Gaines, R.R., 2014, Burgess Shale-type preservation and its distribution in space and

522 time. Reading and Writing of the Fossil Record: Preservational Pathways to Exceptional

523 Fossilization: Paleontological Society Papers, v. 20, p. 123-146.

524 Gaines, R.R., and Droser, M.L., 2003, Paleoecology of the familiar trilobite Elrathia kingii: An

525 early exaerobic zone inhabitant: Geology, v. 31, p. 941-944. 
526 Gaines, R.R., and Droser, M.L., 2005, New approaches to understanding the mechanics of

527 Burgess Shale-type deposits: from the micron scale to the global picture: Sedimentary

$528 \quad$ Record v. 3, p. 4-8.

529 Gaines, R.R., and Droser, M.L., 2010, The paleoredox setting of Burgess Shale-type

530 deposits: Palaeogeography, Palaeoclimatology, Palaeoecology, v. 297, p. 649-661.

531 Gaines, R.R., Briggs, D.E., and Yuanlong, Z., 2008, Cambrian Burgess Shale-type deposits

532 share a common mode of fossilization: Geology, v. 36, p. 755-758.

533 Gaines, R.R., Kennedy, M.J., and Droser, M.L., 2005, A new hypothesis for organic preservation

534 of Burgess Shale taxa in the middle Cambrian Wheeler Formation, House Range,

535 Utah: Palaeogeography, Palaeoclimatology, Palaeoecology, v. 220, p. 193-205.

536 Garson, D.E., Gaines, R.R., Droser, M.L., Liddell, W.D. and Sappenfield, A., 2012, Dynamic

537 palaeoredox and exceptional preservation in the Cambrian Spence Shale of Utah: Lethaia, $538 \quad$ v. 45, p. $164-177$.

539 Goloboff, P., and Catalano, S., 2016, TNT version 1.5, including a full implementation of 540 phylogenetic morphometrics: Cladistics, v. 32, p. 221-238.

541 Gunther, L. F., and Gunther, V. G., 1981, Some Middle Cambrian fossils of Utah: Brigham $542 \quad$ Young University Geology Studies, v. 28, p. 1-81.

543 Halgedahl, S.L., Jarrard, R.D., Brett, C.E., and Allison, P.A., 2009, Geophysical and geological 544 signatures of relative sea level change in the upper Wheeler Formation, Drum Mountains, $545 \quad$ West-Central Utah: a perspective into exceptional preservation of 546 fossils: Palaeogeography, Palaeoclimatology, Palaeoecology, v. 277, p. 34-56.

547 Hendricks, J.R., 2013, Global distributional dynamics of Cambrian clades as revealed by 548 Burgess Shale-type deposits: Geological Society, London, Memoirs, v. 38, p. 35-43. 
Hendricks, J.R., and Lieberman, B.S., 2008, New phylogenetic insights into the Cambrian radiation of arachnomorph arthropods: Journal of Paleontology, v. 82, p. 585-594.

551 Hendricks, J.R., Lieberman, B.S. and Stigall, A.L., 2008, Using GIS to study palaeobiogeographic and macroevolutionary patterns in soft-bodied Cambrian arthropods: Palaeogeography, Palaeoclimatology, Palaeoecology, v. 264, p. 163-175.

554 Hou, X., Bergström, J. and Ahlberg, P., 1995, Anomalocaris and other large animals in the 555 Lower Cambrian Chengjiang fauna of southwest China: GFF, v. 117, p. 163-183.

556 Johnston, P.A., Johnston, K.J., Collom, C.J., Powell, W.G. and Pollock, R.J., 2009,

557 Palaeontology and depositional environments of ancient brine seeps in the Middle

558 Cambrian Burgess Shale at The Monarch, British Columbia, Canada: Palaeogeography, 559 Palaeoclimatology, Palaeoecology, v. 277, p. 86-105.

560 Kloss, T.J., Dornbos, S.Q., Chen, J.Y., McHenry, L.J., and Marenco, P.J., 2015, High-resolution 561 geochemical evidence for oxic bottom waters in three Cambrian Burgess Shale-type 562 deposits: Palaeogeography, Palaeoclimatology, Palaeoecology, v. 440, p. 90-95.

563 Lerosey-Aubril, R., Hegna, T.A., Kier, C., Bonino, E., Habersetzer, J., and Carré, M., 2012, 564 Controls on gut phosphatisation: the trilobites from the Weeks Formation Lagerstätte 565 (Cambrian; Utah): PLoS One, v7, p. e32934.

566 Lerosey-Aubril, R., Hegna, T.A., Babcock, L.E., Bonino, E., and Kier, C., 2014, Arthropod 567 appendages from the Weeks Formation Konservat-Lagerstätte: new occurrences of 568 anomalocaridids in the Cambrian of Utah, USA: Bulletin of Geosciences, v. 89, p. 269$569 \quad 282$. 
570 Liddell, W.D., Wright, S.W. and Brett, C.E., 1997, Sequence stratigraphy and paleoecology of 571 the Middle Cambrian Spence Shale in northern Utah and southern Idaho: Brigham Young $572 \quad$ University Geology Studies, v. 42, p. 59-78.

573 LoDuca, S.T., Caron, J.B., Schiffbauer, J.D., Xiao, S., and Kramer, A., 2015, A reexamination of 574 Yuknessia from the Cambrian of British Columbia and Utah: Journal of Paleontology, v. $575 \quad 89$, p. $82-95$.

576 Liu, Q., 2013, The first discovery of anomalocaridid appendages from the Balang Formation 577 (Cambrian Series 2) in Hunan, China: Alcheringa, v. 37, p. 1-6.

578 Maddison, W.P., and Maddison, D.R., 2017, Mesquite: a modular system for evolutionary $579 \quad$ analysis. Version 3.2: http://mesquiteproject.org.

580 Moore, R.A., Lieberman, B.S., 2009, Preservation of early and Middle Cambrian soft-bodied 581 arthropods from the Pioche Shale, Nevada, USA: Palaeogeography, Palaeoclimatology, Palaeoecology, v. 277, p. 57-62.

Olcott Marshall, A., Wehrbein, R.L., Lieberman, B.S. and Marshall, C.P., 2012, Raman spectroscopic investigations of Burgess Shale-type preservation: a new way forward: Palaios, v. 27, p. 288-292.

Rees, M.N., 1986, A fault-controlled trough through a carbonate platform: The Middle Cambrian House Range embayment: Geological Society of America Bulletin, v. 97, p. 1054-1069.

Resser, C.E., 1939, The Spence shale and its fauna, (with six plates): Smithsonian Institution Miscellaneous Collections, v. 97, p. 1-29.

591

Robison, R.A., 1964, Late Middle Cambrian faunas from western Utah: Journal of Paleontology, v. 38 , p. $510-566$. 
592 Robison, R. A. 1965, Middle Cambrian eocrinoids from western North America: Journal of 593 Paleontology, v. 39, p. 355-364.

594 Robison, R.A., 1991, Middle Cambrian biotic diversity: examples from four Utah Lagerstätten, 595 in Simonetta, A. and Conway Morris, S., ed, The early evolution of metazoa and the significance of problematic taxa: Cambridge University Press, Cambridge, p.77-98.

597 Robison, R.A. and Babcock, L.E., 2011, Systematics, paleobiology, and taphonomy of some 598 exceptionally preserved trilobites from Cambrian Lagerstätten of Utah: Paleontological

Robison, R.A. and Richards, B.C., 1981, Larger bivalve arthropods from the Middle Cambrian of Utah: University of Kansas Paleontological Contributions, v. 106, p. 1-28

602 Robison, R.A. and Wiley, E.O., 1995, A new arthropod, Meristosoma: more fallout from the 603 Cambrian explosion: Journal of Paleontology, v. 69, p. 447-459.

604 Robison, R.A., Babcock, L.E., and Gunther, V.G., 2015, Exceptional Cambrian fossils from 605 Utah: a window into the Age of Trilobites: Utah Geological Survey Miscellaneous Publications, v. 15, p. 1-97.

607 Rogers, J.C., 1984, Depositional environments and paleoecology of two quarry sites in the Middle Cambrian Marjum and Wheeler Formations, House Range, Utah: Brigham Young University Geology Studies, v. 31, p. 97-115.

610 Stein, M., 2013, Cephalic and appendage morphology of the Cambrian arthropod Sidneyia inexpectans: Zoologischer Anzeiger-A Journal of Comparative Zoology, v. 253, p. 164178.

613 Stein, M., Church, S.B., and Robison, R.A., 2011, A new Cambrian arthropod, Emeraldella 614 brutoni, from Utah: Paleontological Contributions, v. 3, p.1-9. 
615 Van Roy, P., and Briggs, D.E., 2011, A giant Ordovician anomalocaridid: Nature, v. 473, p.510$616 \quad 513$.

617 Van Roy, P., Daley, A.C., and Briggs, D.E.G., 2015, Anomalocaridid trunk limb homology 618 revealed by a giant filter-feeder with paired flaps. Nature, v. 522, p. 77-80.

619 Vinther, J., Stein, M., Longrich, N.R., and Harper, D.A., 2014, A suspension-feeding 620 anomalocarid from the Early Cambrian: Nature, v. 507, p. 496-499.

621 Walcott, C. D., 1911, Middle Cambrian holothurians and medusa: Smithsonian Miscellaneous 622 Collections, v. 57, p. 41-68.

623 Walcott, C. D., 1912, Middle Cambrian Brachiopoda, Malacostraca, Trilobita and Merostomata: 624 Smithsonian Miscellaneous Collections, v. 57, p. 145-288.

625 Whiteaves, J. F., 1892, Description of a new genus and species of phyllocarid Crustacea from the 626 Middle Cambrian of Mount Stephen, B.C.: Canadian Record of Science, v. 5, p. 205-208. 627 Whittington, H.B., and Briggs, D.E., 1985, The largest Cambrian animal, Anomalocaris, Burgess 628 Shale, British Columbia: Philosophical Transactions of the Royal Society of London. 629 Series B, Biological Sciences, v. 309, p.569-609.

\section{Figure captions}

633 Figure 1. Stratigraphic column showing relative ages of Burgess Shale, Spence Shale, Wheeler

634 Formation, Marjum Formation and Weeks Formation, with reference to global

635 chronostratigraphic units and polymerid trilobite biostratigraphy. Adapted from Robison et al. 636 (2015). 
638 Figure 2. Hurdiid appendages and oral cones from the Spence Shale Member, Langston

639 Formation, Wellsville Mountains, Utah, USA. (1) Appendage KUMIP 314145; (2) appendage

640 KUMIP 314178; (3) appendage KUMIP 314040a with arrow indicating broken ventral spine; (4)

641 KUMIP 314040b, counterpart to 3; (5) appendage KUMIP 314042; (6) oral cone KUMIP

642 314175a; (7) oral cone KUMIP 314265a; All scale bars represent $5 \mathrm{~mm}$.

644 Figure 3. Assemblage of two Hurdia appendages with an oral cone (1) KUMIP 312405a; (2)

645 KUMIP 312405b, counterpart to 1; (3) interpretative drawing of 2. Abbreviations: app. $1=$ 646 appendage 1 , app. $2=$ appendage 2 , as $=$ auxiliary spine, $1 \mathrm{p}=$ large plate, $\mathrm{p} 1=$ podomere $1, \mathrm{p} 6=$

647 podomere $6, \operatorname{tr}=$ tooth row, ts $=$ terminal spine, $v s=$ ventral spine. All scale bars represent 10 $648 \mathrm{~mm}$.

650 Figure 4. Hurdia carapace elements and flap from the Spence Shale Member, Langston 651 Formation, Wellsville Mountains, Utah, USA. (1) H-element KUMIP 314050; (2) H-element 652 KUMIP 314039; (3) H-element 314058; (4) Boxed region in 1; (5) Boxed region in 3; (6) flap 653 KUMIP 314057b; (7) KUMIP 314057a, part to 6. Scale bars in 1-3, 6, 7 represent $10 \mathrm{~mm}$, scale 654 bars in $\mathbf{4}, \mathbf{5}$ represent $2.5 \mathrm{~mm}$.

656 Figure 5. Hurdiid appendages, oral cones and carapace element from the Wheeler Formation, 657 House Range, Utah, USA. (1) Appendage KUMIP 314086b; (2) KUMIP 314086a, part to 1; (3) 658 appendage KUMIP 204781a; (4) KUMIP 204781b, counterpart to 3; (5) oral cone KUMIP 659 314094; (6) Hurdia P-element 153901a; (7) KUMIP 153901b, counterpart to 6; (8) oral cone 
661 153093a, part to 10. All scale bars represent $10 \mathrm{~mm}$.

663 Figure 6. Peytoia partial body and partial oral cone from the Marjum Formation, House Range,

664 Utah, USA, USNM 374593 (1) Counterpart; (2) part; (3) box from 1, showing flap and

665 strengthening rays; (4) box from 2, arrow indicates high relief linear structures; (5) interpretive

666 sketch of 1. Abbreviations: ba = body axis, s1-11 = setal blade blocks, labelled anterior to

667 posterior, $\mathrm{df}=$ dorsal flap, $\mathrm{g}=$ gut, $\mathrm{hr} ?=$ head region?, $\mathrm{m} 1-6=$ muscle blocks, labelled anterior

668 to posterior, $\mathrm{st}=$ staples, $\mathrm{t}=$ tail, $\mathrm{vf}=$ ventral flap; (6) partial oral cone KUMIP 314095b; (7) part

669 to 6; All scale bars represent $10 \mathrm{~mm}$.

671 Figure 7. Comparison of musculature in Peytoia partial body from the Marjum Formation,

672 House Range, Utah, USA, and Anomalocaris from the Burgess Shale, British Columbia, Canada.

673 (1) USNM 374593, box 7.1 from Fig. 6.1, showing position of musculature at the base of flaps;

674 (2) ROM 62547, showing position of musculature at the base of flaps; (3) box from 1, showing

675 faint linear features in musculature; (4) box from 2, showing clear linear features in musculature

676 (5) box 7.5 from Fig. 6.1, showing linear features in matrix where musculature has been

677 removed. Scale bars in $\mathbf{1 , 2}$, represent $10 \mathrm{~mm}$. Scale bars in $\mathbf{3 , 4 , 5}$ represent $1 \mathrm{~mm}$.

679 Figure 8. 3D model of Hurdia appendage, with ventral spines reconstructed as being of equal 680 thickness. (1) Lateral view, showing ventral spines appearing equally thick; (2) oblique view, 
681 showing distal ventral spines appearing thicker than proximal ones, and differences in 'hooked' 682 appearance at distal tip of ventral spines.

683

\section{Table captions}

685

686 Table 1. Specimens examined in this study, including original and new taxonomic 687 interpretations.

Table 2. Locations containing hurdiid specimens. Abbreviations: HCM = Holy Cross

690 Mountains, Poland; Shuj. = Shuijingtuo Formation, China; Balang = Balang Formation, China;

691 Jince $=$ Jince Formation, Czech Republic; Spence $=$ Langston Formation (Spence Shale

692 Member), Utah, USA; Tulip = Tulip Beds, Mount Stephen, Yoho National Park, Canada; Burg.

693 = Fossil Ridge, Burgess Shale, Yoho National Park Canada; Stan. = Stanley Glacier, Kootenay

694 National Park, Canada; Wheel. = Wheeler Formation, Utah, USA; Marj. = Marjum Formation,

695 Utah, USA; Fez. = Fezouata Formation, Morocco. Publications: 1=Daley and Legg (2015);

696 2=Cui and Hou (1990); 3=Lui (2013); 4= Chlupáč and Kordule (2002); 5=Conway Morris and

697 Robison (1988); 6=Briggs et al. (2008); 7=Daley and Budd (2010); 8=Caron et al. (2010);

698 9=Robison and Richards (1981); 10=Briggs and Robison (1984); 11=Van Roy and Briggs

699 (2011). 


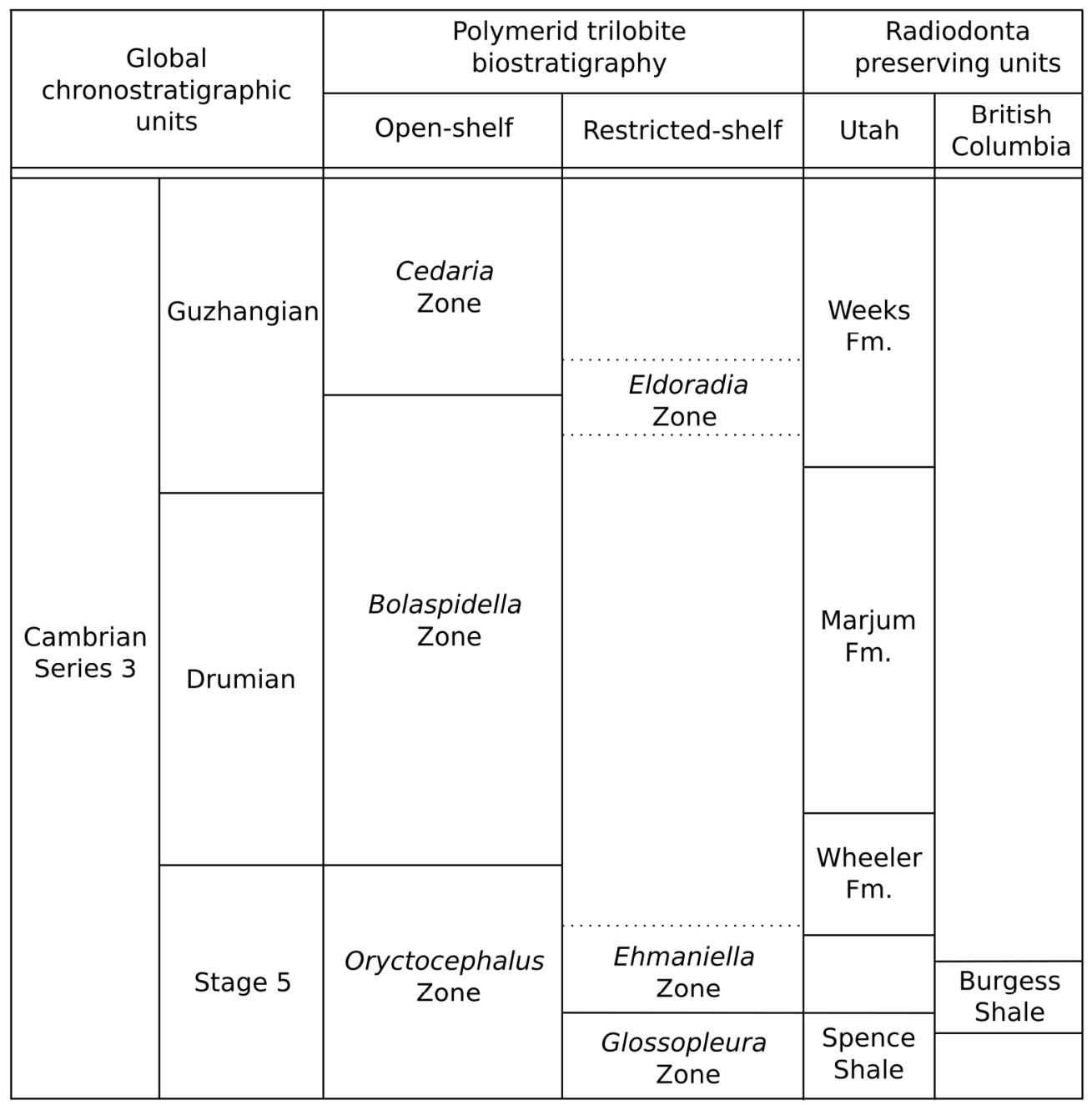

Stratigraphic column showing relative ages of Burgess Shale, Spence Shale, Wheeler Formation, Marjum Formation and Weeks Formation, with reference to global chronostratigraphic units and polymerid trilobite biostratigraphy. Adapted from Robison et al. (2015).

Figure 1

$180 \times 182 \mathrm{~mm}(300 \times 300 \mathrm{DPI})$ 

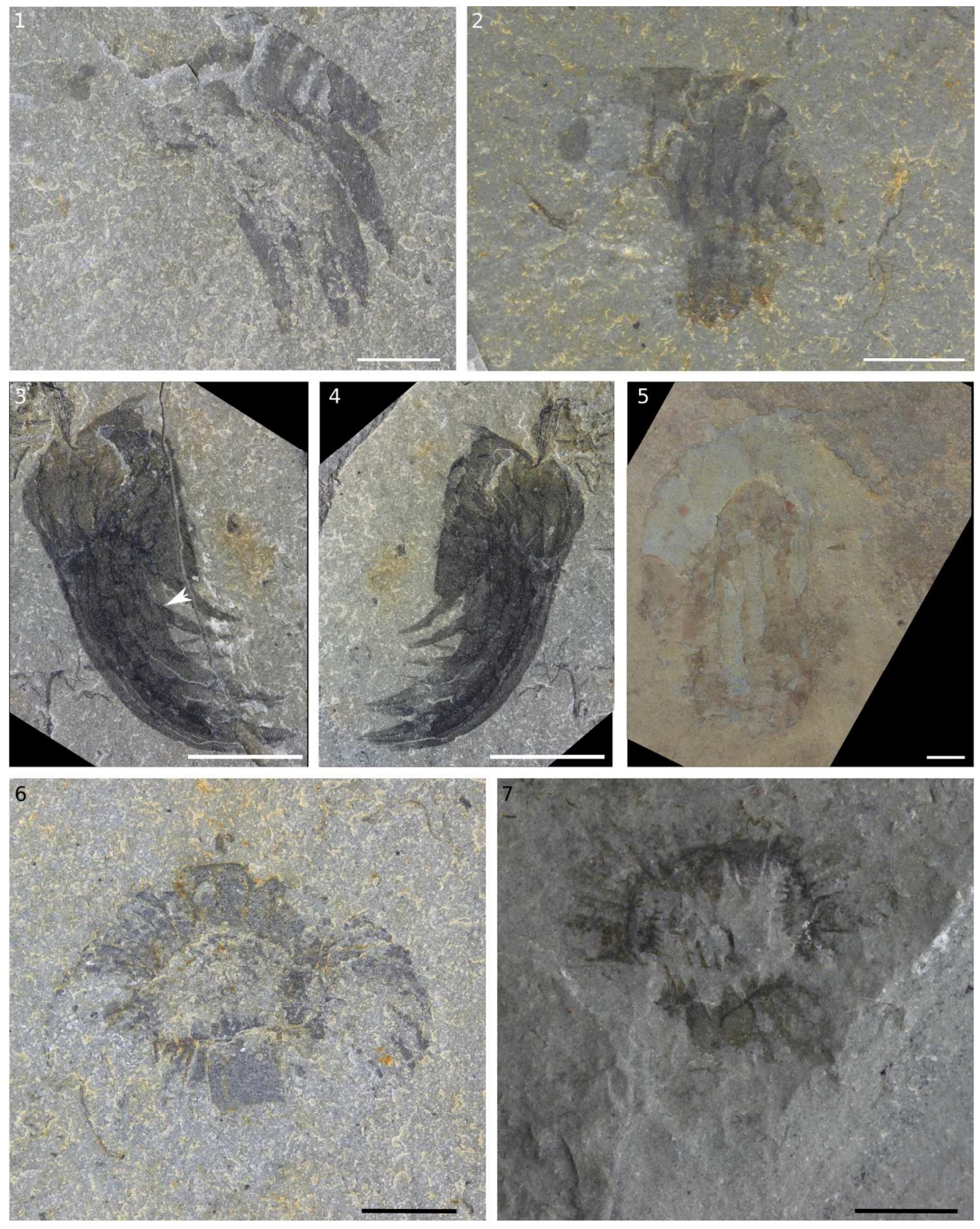

Hurdiid appendages and oral cones from the Spence Shale Member, Langston Formation, Wellsville Mountains, Utah, USA. (1) Appendage KUMIP 314145; (2) appendage KUMIP 314178; (3) appendage KUMIP 314040 a with arrow indicating broken ventral spine; (4) KUMIP 314040b, counterpart to 3; (5) appendage KUMIP 314042; (6) oral cone KUMIP 314175a; (7) oral cone KUMIP 314265a; All scale bars represent 5 $\mathrm{mm}$.

Figure 2

$170 \times 214 \mathrm{~mm}(300 \times 300 \mathrm{DPI})$ 

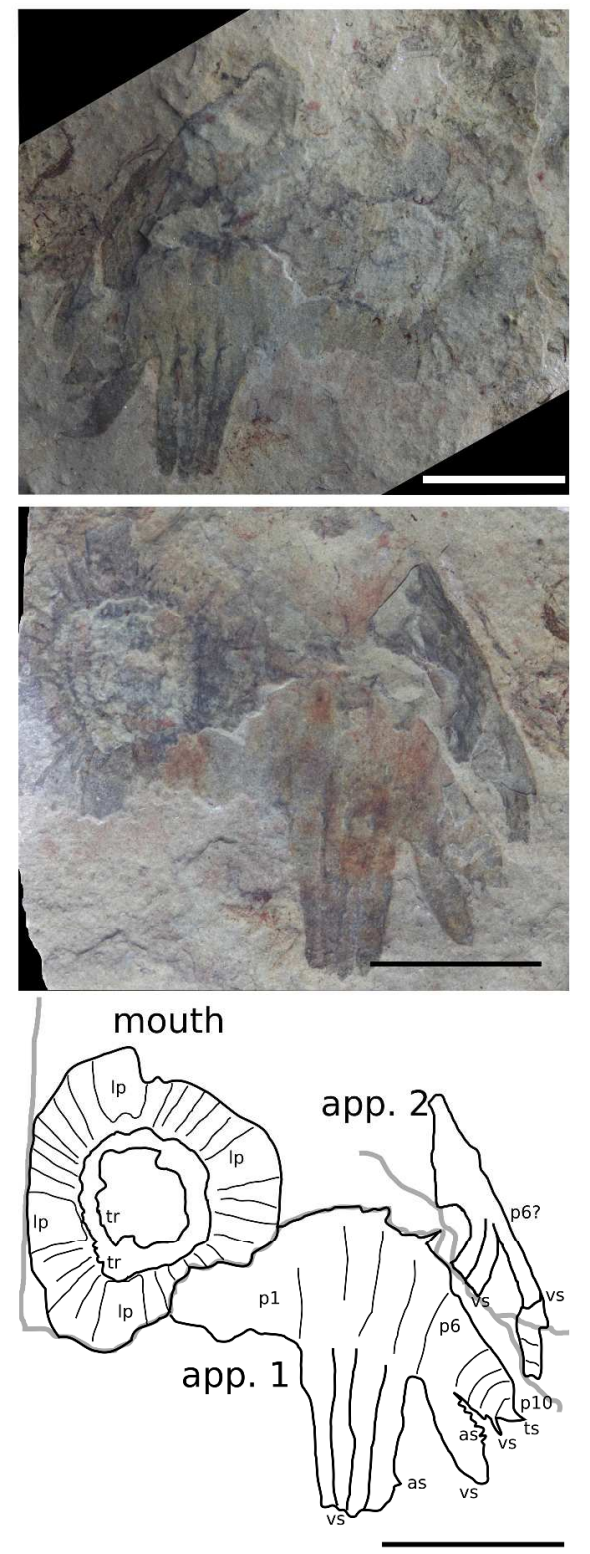

Assemblage of two Hurdia appendages with an oral cone (1) KUMIP 312405a; (2) KUMIP 312405b, counterpart to 1 ; (3) interpretative drawing of 2 . Abbreviations: app. $1=$ appendage 1, app. $2=$ appendage 2 , as = auxiliary spine, $\mathrm{Ip}=$ large plate, $\mathrm{p} 1=$ podomere $1, \mathrm{p} 6=$ podomere $6, \mathrm{tr}=$ tooth row, ts $=$ terminal spine, vs = ventral spine. All scale bars represent $10 \mathrm{~mm}$.

Figure 3

$242 \times 670 \mathrm{~mm}(600 \times 600 \mathrm{DPI})$ 

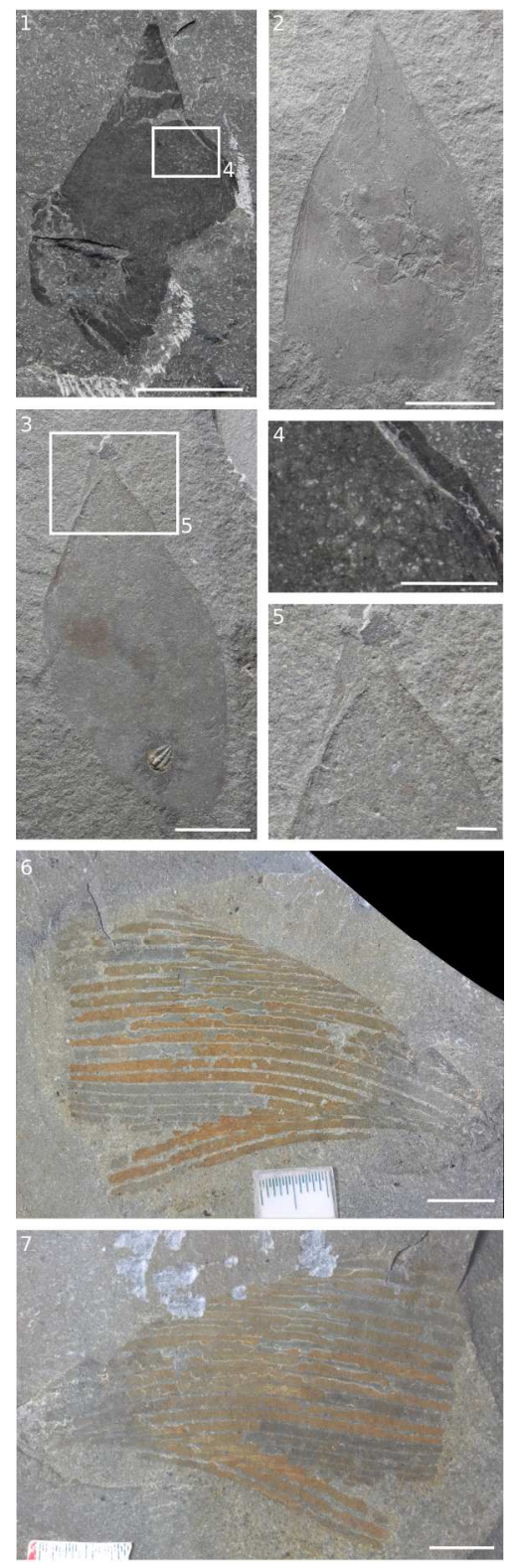

Hurdia carapace elements and flap from the Spence Shale Member, Langston Formation, Wellsville Mountains, Utah, USA. (1) H-element KUMIP 314050; (2) H-element KUMIP 314039; (3) H-element 314058; (4) Boxed region in 1; (5) Boxed region in 3; (6) flap KUMIP 314057b; (7) KUMIP 314057a, part to 6. Scale bars in $1-3,6,7$ represent $10 \mathrm{~mm}$, scale bars in 4,5 represent $2.5 \mathrm{~mm}$.

Figure 4

$85 \times 270 \mathrm{~mm}(300 \times 300 \mathrm{DPI})$ 

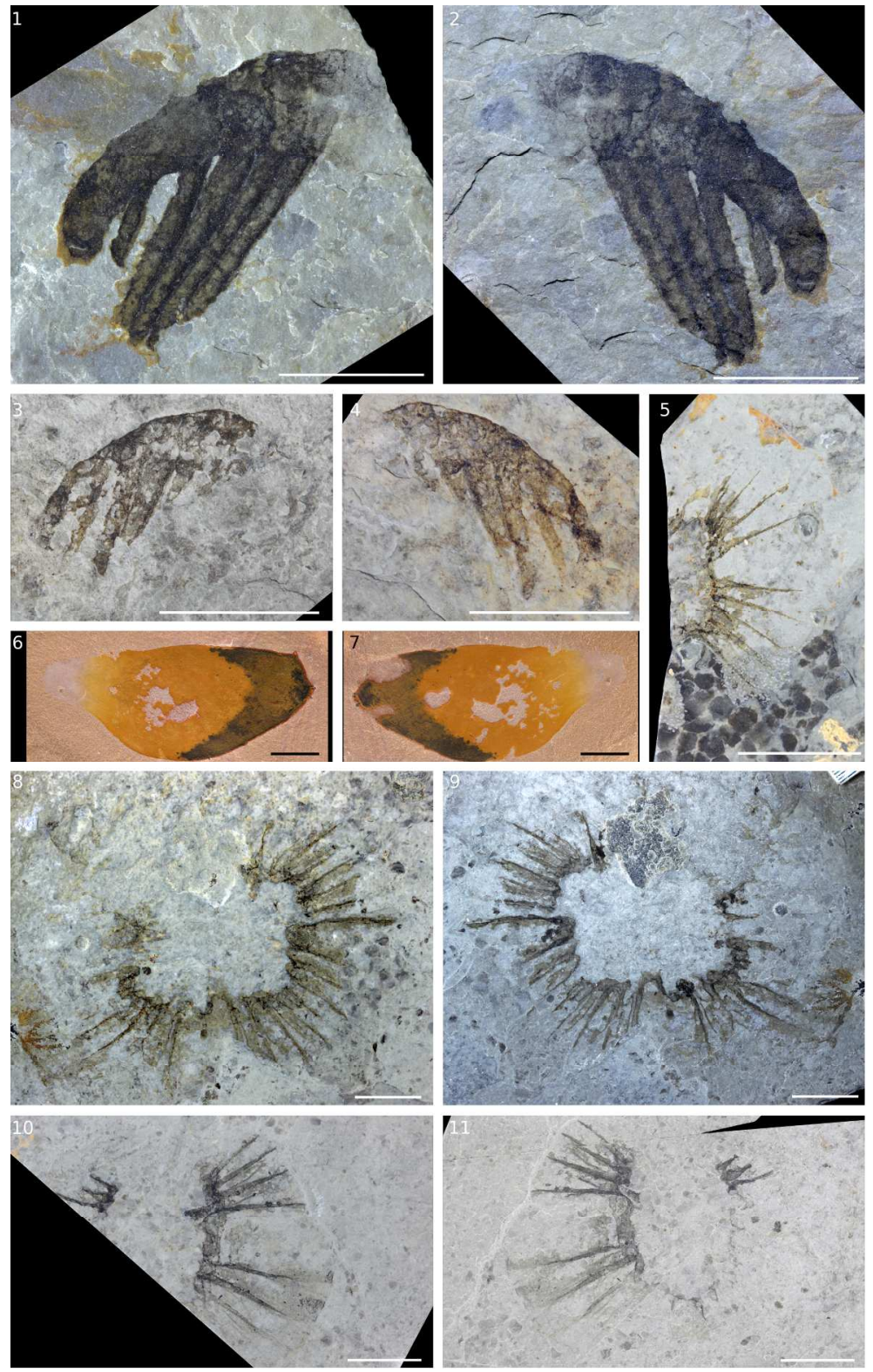

Hurdiid appendages, oral cones and carapace element from the Wheeler Formation, House Range, Utah, USA. (1) Appendage KUMIP 314086b; (2) KUMIP 314086a, part to 1; (3) appendage KUMIP 204781a; (4) KUMIP 204781b, counterpart to 3; (5) oral cone KUMIP 314094; (6) Hurdia P-element 153901a; (7) KUMIP 153901b, counterpart to 6; (8) oral cone KUMIP 314078b; (9) KUMIP 314078a, part to 8; (10) oral cone KUMIP 153093b; (11) KUMIP 153093a, part to 10. All scale bars represent $10 \mathrm{~mm}$.

Figure 5

$170 \times 270 \mathrm{~mm}(300 \times 300$ DPI $)$ 

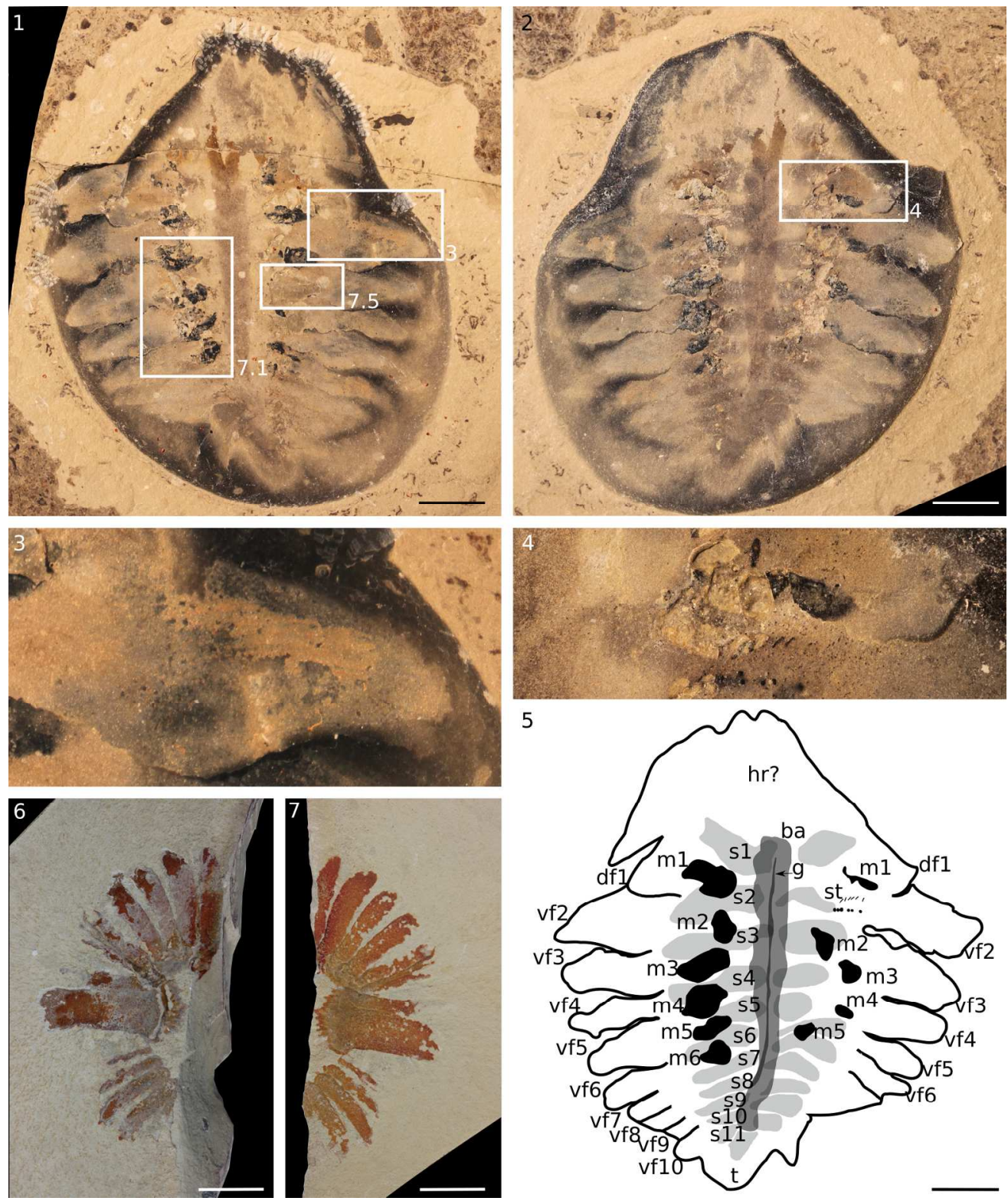

Peytoia partial body and partial oral cone from the Marjum Formation, House Range, Utah, USA, USNM 374593 (1) Counterpart; (2) part; (3) box from 1, showing flap and strengthening rays; (4) box from 2, arrow indicates high relief linear structures; (5) interpretive sketch of 1 . Abbreviations: ba = body axis, s111 = setal blade blocks, labelled anterior to posterior, $\mathrm{df}=$ dorsal flap, $\mathrm{g}=\mathrm{gut}$, hr? = head region?, $\mathrm{m} 1-6=$ muscle blocks, labelled anterior to posterior, st $=$ staples, $t=$ tail, $\mathrm{vf}=$ ventral flap; $(6)$ partial oral cone KUMIP 314095b; (7) part to 6; All scale bars represent $10 \mathrm{~mm}$.

Figure 6

$170 \times 202 \mathrm{~mm}(300 \times 300 \mathrm{DPI})$ 

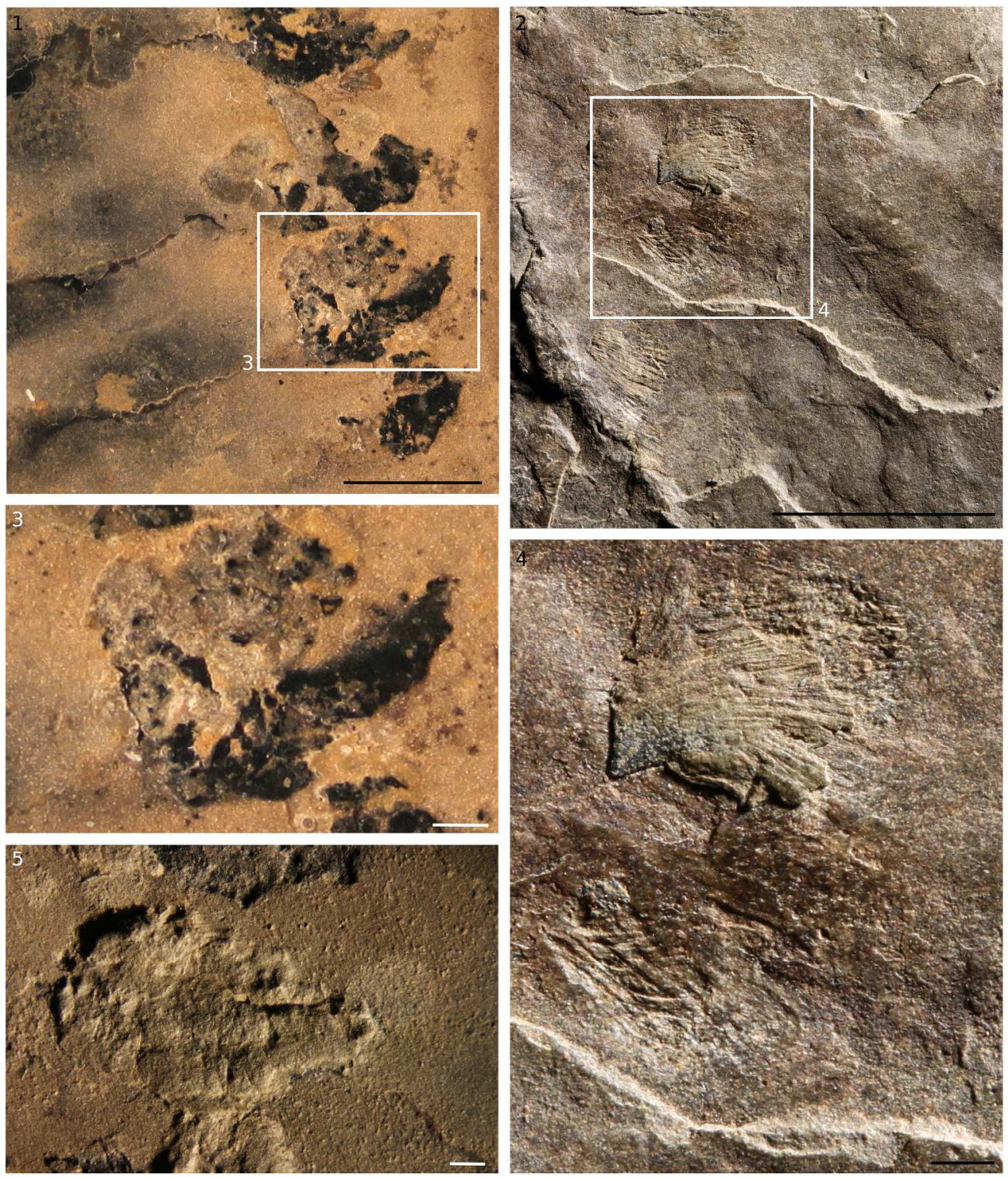

Comparison of musculature in Peytoia partial body from the Marjum Formation, House Range, Utah, USA, and Anomalocaris from the Burgess Shale, British Columbia, Canada. (1) USNM 374593, box 7.1 from Fig. 6.1 , showing position of musculature at the base of flaps; (2) ROM 62547, showing position of musculature at the base of flaps; (3) box from 1, showing faint linear features in musculature; (4) box from 2, showing clear linear features in musculature (5) box 7.5 from Fig. 6.1, showing linear features in matrix where musculature has been removed. Scale bars in 1, 2, represent $10 \mathrm{~mm}$. Scale bars in 3, 4, 5 represent $1 \mathrm{~mm}$.

Figure 7

$209 \times 245 \mathrm{~mm}(300 \times 300$ DPI $)$ 


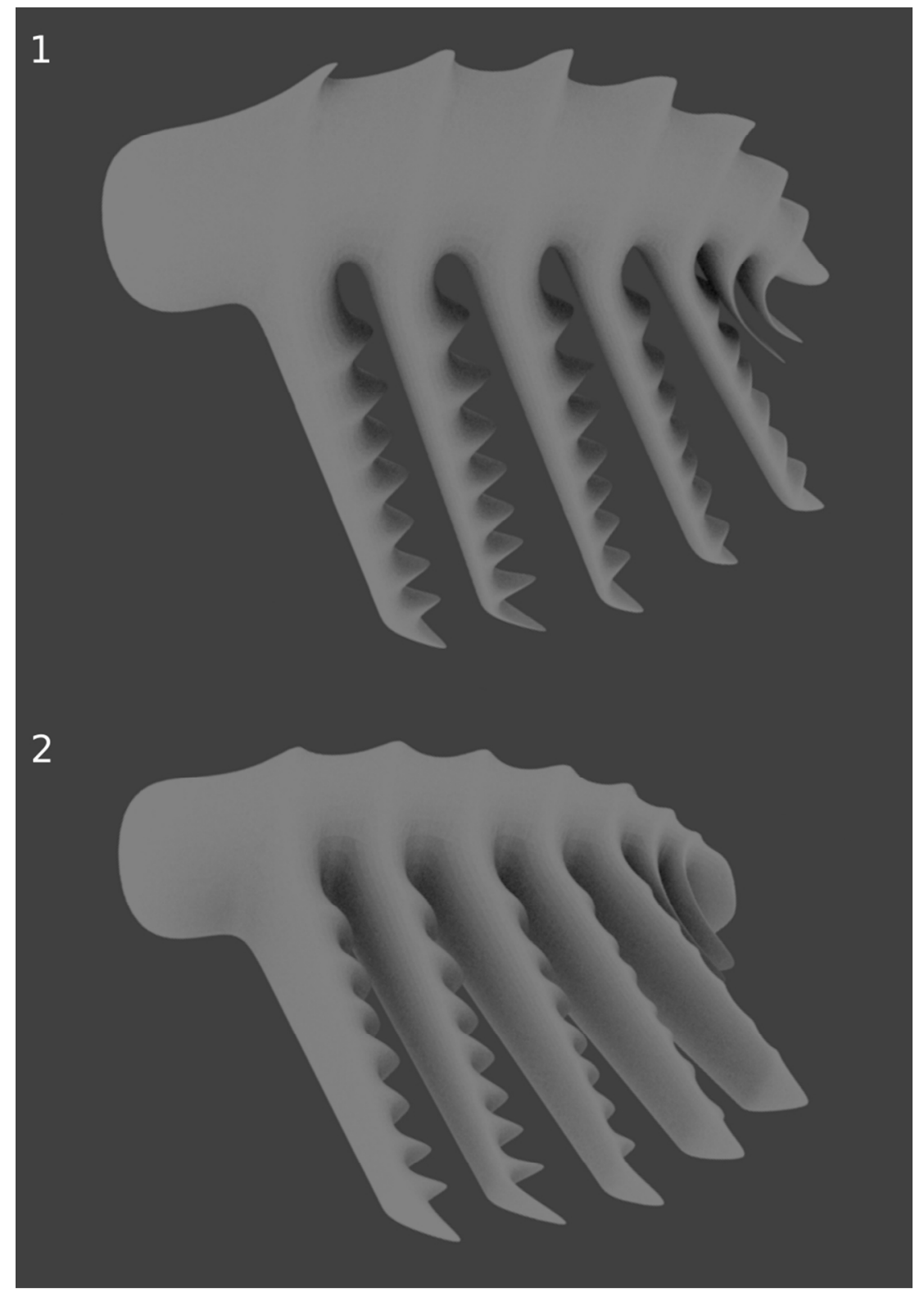

. 3D model of Hurdia appendage, with ventral spines reconstructed as being of equal thickness. (1) Lateral view, showing ventral spines appearing equally thick; (2) oblique view, showing distal ventral spines appearing thicker than proximal ones, and differences in 'hooked' appearance at distal tip of ventral spines.

Figure 8

$85 \times 121 \mathrm{~mm}(300 \times 300 \mathrm{DPI})$ 


\begin{tabular}{|c|c|c|c|c|c|c|}
\hline $\begin{array}{l}\text { Catalogue } \\
\text { number }\end{array}$ & Figure & $\begin{array}{l}\text { Locality } \\
\text { Age }\end{array}$ & Previous interpretation & Reference & $\begin{array}{l}\text { New } \\
\text { interpretation }\end{array}$ & Fragment \\
\hline $\begin{array}{l}\text { KUMIP } \\
153093 a / b\end{array}$ & $5.10,5.11$ & $\begin{array}{l}\text { Wheeler Formation } \\
\text { Cambrian Drumian }\end{array}$ & Peytoia cf. nathorsti & $\begin{array}{l}\text { Conway Morris \& } \\
\text { Robison, } 1982\end{array}$ & $\begin{array}{l}\text { Peytoia } \\
\text { nathorsti }\end{array}$ & Mouthpart \\
\hline $\begin{array}{l}\text { KUMIP } \\
153094\end{array}$ & 5.5 & $\begin{array}{l}\text { Wheeler Formation } \\
\text { Cambrian Drumian }\end{array}$ & Peytoia cf. nathorsti & $\begin{array}{l}\text { Conway Morris \& } \\
\text { Robison, } 1982\end{array}$ & $\begin{array}{l}\text { Peytoia } \\
\text { nathorsti }\end{array}$ & Mouthpart \\
\hline $\begin{array}{l}\text { KUMIP } \\
153901 \mathrm{a} / \mathrm{b}\end{array}$ & $5.6,5.7$ & $\begin{array}{l}\text { Wheeler Formation, } \\
\text { Cambrian Drumian }\end{array}$ & $\begin{array}{l}\text { Proboscocaris agnosta } \\
\text { Hurdia }\end{array}$ & $\begin{array}{l}\text { Robison \& Richards, } \\
\text { 1981; } \\
\text { Daley et al., 2013a }\end{array}$ & Hurdia & P-element \\
\hline $\begin{array}{l}\text { KUMIP } \\
204777- \\
204780\end{array}$ & $\begin{array}{l}\text { Conway } \\
\text { Morris and } \\
\text { Robison, } \\
1988 \text {, figs. } \\
26.1 \text { a, } \\
26.1 b, 26.2\end{array}$ & $\begin{array}{l}\text { Spence Shale } \\
\text { Cambrian Stage } 5\end{array}$ & Peytoia cf. nathorsti & $\begin{array}{l}\text { Conway Morris \& } \\
\text { Robison, } 1988\end{array}$ & $\begin{array}{l}\text { Sidneyia-like } \\
\text { taxon }\end{array}$ & Appendage \\
\hline $\begin{array}{l}\text { KUMIP } \\
204781 a / b\end{array}$ & $5.3,5.4$ & $\begin{array}{l}\text { Wheeler Formation } \\
\text { Cambrian Drumian }\end{array}$ & $\begin{array}{l}\text { Peytoia nathorsti } \\
\text { Hurdia }\end{array}$ & $\begin{array}{l}\text { Conway Morris \& } \\
\text { Robison, 1988; } \\
\text { Daley et al., 2013a }\end{array}$ & hurdiid & Appendage \\
\hline $\begin{array}{l}\text { KUMIP } \\
312405 a / b\end{array}$ & 3 & $\begin{array}{l}\text { Spence Shale } \\
\text { Cambrian Stage } 5\end{array}$ & $\begin{array}{l}\text { Anomalocarididae gen. } \\
\text { et sp. indet. }\end{array}$ & Briggs et al., 2008 & Hurdia & $\begin{array}{l}\text { Appendage } \\
\text { and } \\
\text { mouthpart }\end{array}$ \\
\hline $\begin{array}{l}\text { KUMIP } \\
314039\end{array}$ & 4.2 & $\begin{array}{l}\text { Spence Shale } \\
\text { Cambrian Stage } 5\end{array}$ & - & - & Hurdia victoria & H-element \\
\hline $\begin{array}{l}\text { KUMIP } \\
314040 \mathrm{a} / \mathrm{b}\end{array}$ & $2.3,2.4$ & $\begin{array}{l}\text { Spence Shale } \\
\text { Cambrian Stage } 5\end{array}$ & - & - & Hurdia & Appendage \\
\hline $\begin{array}{l}\text { KUMIP } \\
314042\end{array}$ & 2.5 & $\begin{array}{l}\text { Spence Shale } \\
\text { Cambrian Stage } 5\end{array}$ & - & - & Hurdia & Appendage \\
\hline $\begin{array}{l}\text { KUMIP } \\
314050\end{array}$ & $4.1,4.4$ & $\begin{array}{l}\text { Spence Shale } \\
\text { Cambrian Stage } 5\end{array}$ & - & - & Hurdia victoria & H-element \\
\hline
\end{tabular}




\begin{tabular}{|c|c|c|c|c|c|c|}
\hline $\begin{array}{l}\text { KUMIP } \\
314056\end{array}$ & $4.3,4.5$ & $\begin{array}{l}\text { Spence Shale } \\
\text { Cambrian Stage } 5\end{array}$ & - & - & Hurdia victoria & H-element \\
\hline $\begin{array}{l}\text { KUMIP } \\
314057 a / b\end{array}$ & $4.6,4.7$ & $\begin{array}{l}\text { Spence Shale } \\
\text { Cambrian Stage } 5\end{array}$ & - & - & Hurdia & Flap \\
\hline $\begin{array}{l}\text { KUMIP } \\
314078\end{array}$ & $5.8,5.9$ & $\begin{array}{l}\text { Wheeler Formation } \\
\text { Cambrian Drumian }\end{array}$ & $\begin{array}{l}\text { Anomalocarididae gen. } \\
\text { et sp. indet. }\end{array}$ & Briggs et al., 2008 & $\begin{array}{l}\text { Peytoia } \\
\text { nathorsti }\end{array}$ & Mouthpart \\
\hline $\begin{array}{l}\text { KUMIP } \\
314086 a / b\end{array}$ & $5.1,5.2$ & $\begin{array}{l}\text { Wheeler Formation } \\
\text { Cambrian Drumian }\end{array}$ & $\begin{array}{l}\text { Anomalocarididae gen. } \\
\text { et sp. indet. }\end{array}$ & Briggs et al., 2008 & $\begin{array}{l}\text { Peytoia } \\
\text { nathorsti }\end{array}$ & Appendage \\
\hline $\begin{array}{l}\text { KUMIP } \\
314095 a / b\end{array}$ & $6.6,6.7$ & $\begin{array}{l}\text { Marjum Formation } \\
\text { Cambrian Drumian }\end{array}$ & - & - & $\begin{array}{l}\text { Peytoia } \\
\text { nathorsti }\end{array}$ & Mouthpart \\
\hline $\begin{array}{l}\text { KUMIP } \\
314127\end{array}$ & Not figured & $\begin{array}{l}\text { Spence Shale } \\
\text { Cambrian Stage } 5\end{array}$ & - & - & hurdiid & Mouthpart \\
\hline $\begin{array}{l}\text { KUMIP } \\
314145 a / b\end{array}$ & 2.1 & $\begin{array}{l}\text { Spence Shale } \\
\text { Cambrian Stage } 5\end{array}$ & - & - & Hurdia & Appendage \\
\hline $\begin{array}{l}\text { KUMIP } \\
314175 a / b\end{array}$ & 2.6 & $\begin{array}{l}\text { Spence Shale } \\
\text { Cambrian Stage } 5\end{array}$ & - & - & Hurdia & Mouthpart \\
\hline $\begin{array}{l}\text { KUMIP } \\
314178\end{array}$ & 2.2 & $\begin{array}{l}\text { Spence Shale } \\
\text { Cambrian Stage } 5\end{array}$ & - & - & Hurdia & Appendage \\
\hline $\begin{array}{l}\text { KUMIP } \\
314265 a / b\end{array}$ & 2.7 & $\begin{array}{l}\text { Spence Shale } \\
\text { Cambrian Stage } 5\end{array}$ & - & - & Hurdia & Mouthpart \\
\hline $\begin{array}{l}\text { USNM } \\
374593\end{array}$ & 6,7 & $\begin{array}{l}\text { Marjum Formation } \\
\text { Cambrian Drumian }\end{array}$ & Peytoia nathorsti & Briggs \& Robison, 1984 & $\begin{array}{l}\text { Peytoia } \\
\text { nathorsti }\end{array}$ & Body \\
\hline
\end{tabular}


1 Table 2. Locations from which hurdiid specimens are known.

\begin{tabular}{|l|c|c|c|c|c|c|c|c|c|c|c|}
\hline & $\mathrm{HCM}$ & Shui. & Balang & Jince & Spence & Tulip & Burg. & Stan. & Wheel. & Marj. & Fez. \\
\hline $\begin{array}{l}\text { Hurdia specimens } \\
\text { H. victoria H-elements }\end{array}$ & & & & & $\mathrm{Y}$ & $\mathrm{Y}$ & $\mathrm{Y}$ & $\mathrm{Y}$ & & & $\mathrm{Y}$ \\
\hline $\begin{array}{l}\text { H. triangulata H-element } \\
\text { P-element }\end{array}$ & & $\mathrm{Y}$ & & $\mathrm{Y}$ & & $\mathrm{Y}$ & $\mathrm{Y}$ & & $\mathrm{Y}$ & & $\mathrm{Y}$ \\
\hline Appendage & & & & & $\mathrm{Y}$ & $\mathrm{Y}$ & $\mathrm{Y}$ & $\mathrm{Y}$ & & & \\
\hline Oral cones & & & & $\mathrm{Y}$ & $\mathrm{Y}$ & $\mathrm{Y}$ & $\mathrm{Y}$ & & & \\
\hline App. + Oral cone assem. & & & & & & & $\mathrm{Y}$ & $\mathrm{Y}$ & & & \\
\hline Body (partial/complete) & & & & & & $\mathrm{Y}$ & $\mathrm{Y}$ & $\mathrm{Y}$ & & & \\
\hline Isolated flap & & & & & $\mathrm{Y}$ & & & & & & \\
\hline & & & & & & & & & & & \\
\hline $\begin{array}{l}\text { Peytoia specimens } \\
\text { Appendage }\end{array}$ & $\mathrm{Y}$ & & $\mathrm{Y}$ & & & & & & & & \\
\hline Oral cone & & & & & & $\mathrm{Y}$ & $\mathrm{Y}$ & & $\mathrm{Y}$ & $\mathrm{Y}$ & \\
\hline Body (partial/complete) & & & & & & $\mathrm{Y}$ & $\mathrm{Y}$ & & & $\mathrm{Y}$ & \\
\hline & & & & & & & & & & & \\
\hline Other hurdiid appendages & & & & & & $\mathrm{Y}$ & & $\mathrm{Y}$ & $\mathrm{Y}$ & & $\mathrm{Y}$ \\
\hline Publications & 1 & 2 & 3 & 4 & 5,6 & 7 & 7 & 8 & $5,6,9$ & 10 & 11 \\
\hline
\end{tabular}

2 Publications: 1=Daley \& Legg (2015); 2=Cui and Hou (1990); 3=Lui (2013); 4=Chulpac \& Kordule

3 (2002); 5=Conway Morris \& Robison (1988); 6=Briggs et al. (2008); 7=Daley \& Budd 2010; 8=Caron et

4 al., 2010; 9=Robison \& Richards 1981; 10=Briggs \& Robison (1984); 11=Van Roy \& Briggs (2011). 